\title{
CODE SWITCHING USED BY BOY WILLIAM IN BREAKOUT PROGRAM ON NET TV
}

\author{
Dwinesa Anggraeni ${ }^{1}$, Hernalia Citra Dewi ${ }^{2}$ \\ English Education Program, \\ Faculty of Language and Arts, Universitas Indraprasta PGRI \\ ${ }^{1}$ dwinesaa@yahoo.com, ${ }^{2}$ hernaliacitradewil8@gmail.com
}

\begin{abstract}
Abstrak
Penelitian ini bertujuan untuk mengetahui (1) jenis alih kode yang digunakan oleh Boy William dalam program 'Breakout' di Net TV, (2) jenis alih kode paling dominan yang digunakan oleh Boy William dalam program 'Breakout'" di Net TV. Peneliti menggunakan penelitian kualitatif dengan mengumpulkan data dari tiga episode program Breakout di TV, data yang diambil berfokus pada ucapan-ucapan Boy William. terdapat 40 data ditemukan yang diklasifikasikan ke dalam tiga jenis alih kode, yaitu: alih kode intra-sentential, alih kode inter-sentential, dan alih kode tag. Hasil penelitian menunjukkan terdapat 4 alih kode inter-sentential digunakan dalam ucapan-ucapan Boy, 35 alih kode intra-sentential, dan 1 alih kode tag. Singkatnya, dari tiga video yang diteliti penulis terdapat 10\% ucapan menggunakan alih kode inter-sentential, 87,5\% menggunakan intra-sentential, dan 2,5\% alih kode tag yang digunakan Boy William dalam program musik di Net TV. Kemudian, alih kode intra-sentential adalah yang paling sering digunakan si penutur.
\end{abstract}

Kata Kunci: sosiolinguistik, alih kode, pembelajaran Bahasa Inggris

\begin{abstract}
This research is carried out to find out (1) the types of code switching used by Boy William in "Breakout" program on Net TV, (2) the most dominant type of code switching used by Boy William in "Breakout"' program on Net TV? The researchers use descriptive qualitative method by collecting the data from three episodes of Breakout TV program, the data was taken by focusing on Boy William utterances. It's found 40 data that is classified into three types of code switching, there are: inter-sentential code switching, intra-sentential switching, and tag switching. The research result shows that there are 4 inter-sentential code switching used in Boy' utterances, 35 intra-sentential, and 1 of tag switching. In brief, from three videos that the researchers observed there is $10 \%$ utterances of inter-sentential, $87,5 \%$ using intra-sentential, and 2,5\% tag switching used by Boy William in Breakout music program on Net TV. Then, intra-sentential code switching is the most often used by the speaker.
\end{abstract}

Keywords: sociolinguistics, code switching, English learning 


\section{INTRODUCTION}

Human is social creature who needs to connect and to communicate each other. In the term of communication, people need something to make them easier to deliver their feeling, idea, opinion, and so on. People need means to make them link to one another, in this case a common means that people use in everyday communication is language. According to Wardaugh (2006: 1), "language is what the members of a particular society speak.' In the society, it is important for us to use an appropriate language. It is because the message which is going to be delivered will be accepted by the listener or people in that society greatly without any misunderstandings.

In this modern and millennial era, many people have ability to use more than one language or bilingual. Spolsky (1998: 45) defines "'bilingual is a person who has some functional ability in second language." That phenomenon usually called code switching in sociolinguistics. Code switching occurs in bilingual and multilingual community when a person switches from one language, variety, or dialect to another one. People can do code switching in any kinds of situation and domain.

Nowadays, we can get information in the form of visual or audio data easily. Complete information in the form of audio and visual we can find on television footage. In television footage, we often find some public figures or some host who use code switching when they speak in some television programs. One of the television programs which the host use code switching is "Breakout" program on Net TV channel. Therefore, this research aims to highlight the phenomenon of code switching in the utterances of Boy William as the host of Breakout program on Net TV. The purpose of this research is to find out types and the dominant type of code switching used by him. Breakout program is taken as the object of the research because nowadays we often find people, especially youngsters do code switching in television program mostly on music or fashion TV program. The audience of that TV program is mainly youngster. They are teenager and adult people, with the host, Boy William. He often switches his language from Indonesian to English and English to Indonesian as his style and character when speaking or explaining about music and artist.

The present research has several differences from previous studies. The previous study analyzed the data by using code switching theory proposed by Holmes and Blom \& Gumperz (1980). The objects were the recording of episode TV show and transcript of radio's quiz. However, the present study uses Romaine and Hoffman's theories (1991) focusing on the utterances made by Boy William as host of Net TV in "Breakout" program. The researchers use the data of transcript taken from Boy William's utterances in Breakout program on Net TV.

Based on the description above, this study as mentioned above analyzes the types of code switching and the dominant type of code switching used by Boy William in Breakout TV program. This research has several research questions that are going to answer, correspond to the background of the study.

1. What are the types of code switching used by Boy William in "Breakout" program on Net TV?

2. What is the most dominant type of code switching used by Boy William in "Breakout" program on Net TV? 


\section{The Definition of Sociolinguistics}

Fishman in Chaer and Agustina (2004: 3) said that, "sociolinguistics is the study of the characteristics of language varieties, the characteristics of their functions, and the characteristics of the speaker as these three constantly interact, change and change one another within a speech community." In addition, Holmes (2001: 1) says that "sociolinguistics is concerned with the relationship between language and the context in which it is used."

\section{The Definition of Bilingualism}

Bilingualism is an individual's ability to use more than one language variety. Bilingualism is the ability to use two languages. Trudgill (2003: 24) said that "'bilingualism means the ability of an individual to speak two or more languages." Many countries in this world are called bilingual because they have more than one language. They also have ability to speak more than one language.

Nowadays, bilingualism has become a common phenomenon. Social interaction always involves communication among the society members by using language. While in the social interaction, the society members often use more than one language variety on their bases language. It is done by purpose to convey what they mean in communication. This phenomenon is called the development of communication. It commonly happens in almost area of people's life.

\section{The Definition Code Switching}

"Code switching can occur quite frequently in an informal conversation among people who are familiar and have a shared educational, ethnic, and socio-economic background. It is avoided in a formal speech situation among people especially to those who have little in common factors in terms of social status, language loyalty, and formality' (Hoffmann, 1991: 113).

Code switching occurs where there is a change from one clause of language to another clause of language. Brown and Attardo (2000: 84) underlined that "code switching can occur between different languages, dialect or styles within one sentence or adjacency pair.' Hymes (1974: 103) stated that 'code switching has become a common term for alternate us of two or more languages, varieties of language or event speech styles." From theories above, it can be concluded that code switching happens when someone switches his/her language. It can also happen when someone changes his/her dialect or speech style. According to Holmes (1992) "'code switching occurs when the speaker shifted their language from one language to another. Code switching is switched essentially between sentences."

\section{Types of Code Switching}

According to Romaine in Susanto (2008: 47) states that there are three types of code switching. Each of types is discussed below.

1. Intra-Sentential Switching

Intra-sentential code-switching concerns language alternation that occurs within a sentence or a clause boundary. Sometimes it includes mixing within word boundaries. Since intra-sentential code switching occurs within sentence, clause, word boundaries, or phrase. For example: A: Dari jam sepuluh empat lima tekan jam sewelas seprapat kan? (From ten forty-five to eleven fifteen, isn't it?) Sudarsono in Susanto (2008: 50). Further supported by Hoffman (1991) that "it is the switch that 
occurs within sentence. It is often occurred when someone uses one language and suddenly switches into another language in a sentence."

2. Inter-Sentential Switching

Appel\& Muysken in Susanto (2008: 48) stated that ' inter-sentential codes switching is the switch involving movement from one language to other between sentences." This situation may also include a switch from a whole sentence or more than one sentence produced entirely in one language. Inter-sentential switching may serve to emphasize a point made in the other languages in conversation.

The following examples shows inter-sentential code switching from one language to another language: "ini lagu lama, tahun 60an. It's oldies but goodies, they said. Tapi, masih enak kok didengerin." It shows Indonesian bilingual switches from Indonesian to English (Indrawan, 2010: 76). Other example of inter-sentential code switching (Stockwell, 2007: 48): 'we are going to Nicky's house at nine and maybe to the bomb (a night club) afterwards. (Short pause). Kristina bleibt allerdings zu hause sie muss noch arbeiterl (unfortunately Kristina is staying at home because she still has to do work). The example shows if the conversation switches at a sentence boundary, marked with a short pause, at the point where the topic changes to refer the speaker's German housemate.

Further supported by (Hoffman, 1991: 112) ''inter-sentential switching is the switch from one language into another language which occurs between sentences or speech acts."

\section{Tag Switching}

Tag switching involves the insertion of a tag from one language into an utterance which is otherwise entirely in other language. Tags used easily inserted in speech at a number of points in monolingual utterance without break syntactic rules (Romaine in Susanto, 2008: 47). For example:

a. A finnish bilingual switches from finnish to English, for example: Mutta en mə viittinyt, no way!

b. A Spanish bilingual switch from English to Spanish, for example: She is, verdad?

c. An Indonesian bilingual switch from English to Indonesian, for example; It's okay, no problem, ya nggak?

Further supported by (Poplack in Hoffmann, 1991: 113) it is exclamation or tags which is serving as an emblem of the bilingual character. For example, an adult Spanish-American English speaker says. Oh! Ay! It was embarrassing! It was very nice, though, but I was embarrassed (Silva-Corvalan in Hoffmann, 1991: 112).

\section{RESEARCH METHOD}

This research is classified as a qualitative descriptive method, because it analyses the data in the form of utterances descriptively. Qualitative research is used to describe and analyze code switching used by Boy William in "Breakout" program on Net TV. According to Cohen, et. al (168:2007) qualitative research has some purposes, they are; describing and reporting the creation of key concepts, theory generation, and testing. This study is classified as descriptive qualitative since the data are in the form of utterances. 
The data are analyzed descriptively based on the utterance of Boy William in Breakout program on Net TV, on Monday to Friday at 5.00 pm, January 21st -25th 2019.

\section{RESULT AND DISCUSSION}

The findings of this research related to the problems of the study in chapter one (1) What are the types of code switching used by Boy William in Breakout program on Net TV? (2) What is the most dominant type of code switching used by Boy William in Breakout program on Net TV? As it's explained before, the researchers use descriptive qualitative method in describing and explaining the findings. The main data used in this research is the utterances spoken by Boy William in using bilingual language in Breakout TV program. There are three videos from different episodes with different co-hosts starting from the first video with Sheryl Sheinafia as the co-host, with Sheila Dara Aisha in the second video, and the last video with Sivia Azizah as the co-host. Breakout TV program has changed the co-hosts for three times however the main host is still Boy William. According to Romaine in Susanto (2008: 47) there are three types of code switching; 1) intra-sentential code switching, this code switching occurs within sentence, clause, word boundaries, or phrase, 2) inter-sentential codes switching, this code switching is the switch involving movement from one language to other between sentences. This may also include a switch from a whole sentence or more than one sentence produced entirely in one language, 3) Tag switching, this involves the insertion of a tag from one language into an utterance of other language.

Table 1 Analysis

\begin{tabular}{|c|c|c|c|c|}
\hline No & Example & Inter & Intra & Tag \\
\hline 1. & $\begin{array}{l}\text { Anyway, tadi Ed Sharen with Dawn yang kita puterin buat kalian, banyak } \\
\text { banget yang request di Twitter. }\end{array}$ & & $\sqrt{ }$ & \\
\hline 2. & $\begin{array}{l}\text { Dan film ini mengalahkan film-film of the same genre's kaya sekolah Rimba, } \\
\text { lots about the movies. }\end{array}$ & & $\sqrt{ }$ & \\
\hline 3. & Gw inget banget pas loe keluar this is the moment that capture my attention. & & $\sqrt{ }$ & \\
\hline 4. & $\begin{array}{l}\text {...now I wanna know ya elu sebagai Vidi Aldianonya sendiri yang } \\
\text { menyanyikan lagu itu is there any changes to your vocal dari dulu sampe } \\
\text { sekarang... }\end{array}$ & & $\sqrt{ }$ & \\
\hline 5. & But lucky you man! Gara-gara that song you capture the heart of Indonesian. & & $\sqrt{ }$ & \\
\hline 6. & $\begin{array}{l}\text { Tapi anyways guys we just took the past dari vidi nanti to the present and } \\
\text { then the future. }\end{array}$ & & $\sqrt{ }$ & \\
\hline 7. & Megan Trainor meng-cover lagunya Justin Bieber yang Missing Too. & & $\sqrt{ }$ & \\
\hline 8. & He is forty-five kalau gak salah ya. & & $\sqrt{ }$ & \\
\hline 9. & Udaranya juga enak ya, udaranya is good. & & $\sqrt{ }$ & \\
\hline 10. & Tapi anyways kita pengen dengerin elu can I request a song? & & $\sqrt{ }$ & \\
\hline 11. & Serba mandiri, that's good. & & $\sqrt{ }$ & \\
\hline 12. & That's good tapi just for music label apa also artist management gitu? & & $\sqrt{ }$ & \\
\hline 13. & $\begin{array}{l}\text { Tapi anyways, if you just love music and you are not sick of anything you } \\
\text { don't need a doctor. }\end{array}$ & & $\sqrt{ }$ & \\
\hline 14. & Welcome to Breakout sekarang gw lagi nungguin Shella Dara dulu. & & $\sqrt{ }$ & \\
\hline 15. & Buat kalian yang lagi gak nonton di rumah bisa live streaming. & & $\sqrt{ }$ & \\
\hline 16. & $\begin{array}{l}\text { Meski musiknya gak upbeat kita strip down aja pake gitar itu tetep lagu yang } \\
\text { melodinya enak banget. }\end{array}$ & & $\sqrt{ }$ & \\
\hline 17. & Dan kita ada top secret juga... & & $\sqrt{ }$ & \\
\hline
\end{tabular}




\begin{tabular}{|c|l|c|c|c|}
\hline 18. & Thank you mas! & & $\sqrt{ }$ & \\
\hline 19. & Nih gw juga udh pesenin elu your favorite lychee tea. & & $\sqrt{ }$ & \\
\hline 20. & Alright guys yang lagi nonton di rumah ikutan makan juga dung. & & $\sqrt{ }$ & \\
\hline & Numbers & 4 & 35 & 1 \\
\hline
\end{tabular}

These examples represent the analysis of each type and it can be seen clearly as the following:

\section{Discussion}

1. Intra-sentential

\section{Data 1}

"Anyway, tadi Ed Sharen with Dawn yang kita puterin buat kalian, banyak banget yang request di Twitter."

\section{Analysis:}

The speaker starts the conversation by using an English word "anyway" then switch the rest of his explanation by using Indonesian but he inserts again another English word "request." Intra-sentential code switching happens when the speaker switches the conversation from English to Indonesian within sentence. The words like "'anyway", 'request' are used in that sentence indicates the speaker is able to use bilingual language (Indonesian-English).

2. Inter-sentential

a. Data 13

"'Your new latest single tells me about it. Ceritain sedikit tentang itu.',

Analysis:

The speaker uses inter-sentential code switching. He uses English sentence then switches into Indonesian for the next sentence, so the switching happens between sentences.

b. Data 14

'Loe mau promosiin Twitter, Instagram loe, no need, right?"'

Analysis:

The speaker uses an English linguistic tag "right" in his conversation in Indonesian. The speaker ends his conversation with final tag or tag switching.

From the analysis and discussion above, the researchers finally get the result. From three videos of Breakout TV program, 40 data are found and classified into three types of code switching. There are 4 data of inter-sentential of code switching and 35 intra-sentential, and 1 of tag switching. In brief, from 3 videos that the researchers observed there is $10 \%$ of using inter-sentential, $87,5 \%$ using intra-sentential, and 2,5\% of using tag switching used by Boy William in Breakout music TV program on Net TV. It can be seen clearly that inter-sentential code switching is most common used.

\section{CONCLUSION}

The research has done completely after getting result. It can be concluded that from three videos that is used in analyzing the types of code switching uttered by Boy 
William in Breakout TV program on Net TV, the researchers found 40 data. Code switching according to Romaine in Susanto (2008: 47) he classifies code switching into three types, there are intra-sentential, inter-sentential, and tag switching. Based on the result, it is found 35 intra-sentential code-switching type from Boy William utterances, 4 inter-sentential code switching, and 1 tag switching. In other words, $10 \%$ inter-sentential type spoken by Boy William, 87,5 \% for intra-sentential, and 2,5\% for tag switching. Intra-sentential code switching is utterances or expression of one language switched to other language that occurs within sentence, clause, word boundaries, or phrase, and this type is the most commonly used by Boy William in his music TV program. It clearly be seen that intra-sentential code switching is the most dominant type used by the speaker, it shows at the table below as the following:

Table 2 Percentage Analysis

\begin{tabular}{|c|c|c|c|}
\hline No. & Inter-sentential & Intra-sentential & Tag switching \\
\hline 1. & 4 & 35 & 1 \\
\hline 2. & $10 \%$ & $87,5 \%$ & $2,5 \%$ \\
\hline
\end{tabular}

\section{REFERENCES}

Appel, R., \& Muysken. (1987). Langage contact and bilingualism. London: Edward Arnold.

Brown, S., \& Attardo S. (2000). Understanding language structure, interaction, and variation. University of Michigan Press.

Chaer, A., \& Agustina, L. (2004). Sosiolinguistik perkenalan awal. Jakarta: Rineka Cipta

Cohen, L., Manion, L., \& Morrison, K. (2013). Research methods in education. Sixth ed. USA and Canada: Routledge.

Hoffman, C. (1991). An introduction to bilingualism: New York. Longman

Holmes, J. (2001). An introduction to sociolinguistics ( $2^{\text {nd }}$ ed). Pearson Education Limited

Hymes, D. (1974). Foundation in sociolinguistics: Philadelphia: University of Pennsylvania Press.

Romaine, S. (1995). Language in society: An introduction to sociolinguistics. Oxford: University Press.

Spolsky, B (1998). Sociolinguistics. Oxford Introductions to Language Study: Oxford Universit Press.

Stockwell, P. (2007). Sociolinguistics: A resource book for students. London: Routledge. 
Susanto, D. (2006). Code switching in Indonesian Islamic religious discourse: A sociolinguistic perspective. A Thesis Submitted for the Degree of Doctor of Philosophy at the University of Queensland, Australia.

Trudgill, P. (1974). Sociolinguistics: An Introduction. Great Britain: Hazell Watson\& Viney L.td

Wardhaugh, R. (2006). An Introduction to linguistics: Blackwell Publishing. 